\title{
Transforming growth factor- $\alpha$ stimulates proliferation of mammotrophs and corticotrophs in the mouse pituitary
}

\author{
S Oomizu ${ }^{1}$, J Honda ${ }^{1}$, S Takeuchi ${ }^{1}$, T Kakeya ${ }^{1}$, T Masui ${ }^{2}$ and \\ S Takahashi ${ }^{1}$ \\ ${ }^{1}$ Department of Biology, Faculty of Science, Okayama University, Tsushima, Okayama 700-8530, Japan \\ ${ }^{2}$ Cell Bank, National Institute of Health Sciences, Kami-Yoga, Setagaya-ku, Tokyo 158-8501, Japan \\ (Requests for offprints should be addressed to S Takahashi; E-mail: stakaha@cc.okayama-u.ac.jp)
}

\begin{abstract}
Oestrogen stimulates the proliferation of pituitary cells. The present study was designed to clarify the involvement of transforming growth factor- $\alpha$ (TGF- $\alpha$ ) in the oestrogen-induced growth of mouse pituitary cells in vitro. Anterior pituitary cells obtained from ICR male mice were cultured in a primary serum-free culture system. Proliferation of pituitary cells was detected by monitoring the cellular uptake of bromodeoxyuridine. Secretory cell types were immunocytochemically determined. Treatment with TGF- $\alpha(0 \cdot 1$ and $1 \mathrm{ng} / \mathrm{ml})$ for 5 days stimulated cell proliferation. Since TGF- $\alpha$ binds to the epidermal growth factor (EGF) receptor, this action may be exerted through the EGF receptor. Oestradiol-17 $\beta \quad\left(\mathrm{OE}_{2}\right.$, $\left.10^{-9} \mathrm{M}\right)$ stimulated mammotrophic and corticotrophic
\end{abstract}

cell proliferation. RG-13022, an EGF receptor inhibitor, inhibited the cell proliferation induced by EGF or $\mathrm{OE}_{2}$, showing that the EGF receptor was involved in the growth response in mammotrophs and corticotrophs. Treatment with antisense TGF- $\alpha$ oligodeoxynucleotide (ODN) inhibited the cell proliferation induced by $\mathrm{OE}_{2}$, but treatment with antisense EGF ODN did not. RT-PCR analysis revealed that $\mathrm{OE}_{2}$ stimulated TGF- $\alpha$ mRNA and EGF receptor mRNA expression. These results indicate that TGF- $\alpha$ mediates the stimulatory effect of oestrogen on the pituitary cell proliferation in a paracrine or autocrine manner, and that EGF receptor expression is stimulated by oestrogen.

Journal of Endocrinology (2000) 165, 493-501

\section{Introduction}

Much evidence has shown that differentiation and growth of secretory cells and regulation of hormone secretion are partly regulated by growth factors and cytokines produced in the pituitary gland, and also by hormones produced in the hypothalamus and peripheral endocrine organs (Schwartz \& Cherny 1992, Takahashi 1995, Renner et al. 1996, Ray \& Melmed 1997). Growth of mammotrophs is partly regulated by ovarian oestrogen and hypothalamic dopamine (Lloyd et al. 1975, Takahashi \& Kawashima 1987). Oestrogen stimulates not only secretion of prolactin (PRL) from mammotrophs, but also proliferation of mammotrophs (Bethea 1984, Takahashi \& Kawashima 1987, Oomizu \& Takahashi 1996).

The molecular mechanism responsible for oestrogeninduced growth of pituitary cells has not been fully delineated. Several studies indicate that oestrogen action on cell proliferation is indirect and is mediated by growth factors in an autocrine or paracrine manner (Sirbasku 1978, Sutherland et al. 1988). In the case of the growth of pituitary cells, transforming growth factor- $\alpha$ (TGF- $\alpha$ ) is one of the candidates for the oestrogen-induced growth factors (Borgundvaag et al. 1992). TGF- $\alpha$ is produced in pituitary glands of several species (Kudlow \& Kobrin 1984, Kobrin et al. 1987, Lazar \& Blum 1992). In rat pituitary cells, TGF- $\alpha$ mRNA expression was detected in somatotrophs, gonadotrophs and mammotrophs (Fan \& Childs 1995). TGF- $\alpha$ binds to epidermal growth factor (EGF) receptors (Massague 1990). Immunoreactive EGF receptors have been observed in all cell types of the rat pituitary secretory cells, but not in every pituitary cell (Fan \& Childs 1995, Armstrong \& Childs 1997a,b). In primary pituitary cell cultures enriched with adrenocorticotrophic hormone (ACTH)-producing cells (corticotrophs), EGF stimulates corticotroph proliferation (Childs et al. 1995). However, the effect of TGF- $\alpha$ on the proliferation of other subsets of pituitary cells, particularly mammotrophs, remains to be studied. The aims of the present study were to investigate the effects of TGF- $\alpha$ on the proliferation of mouse pituitary cells, and to examine its involvement in oestrogen-induced pituitary growth. The expression of EGF receptors changes with the oestrous cycle in female rats (Armstrong \& Childs 1997a). Therefore, we used male mice to avoid the cyclic change in EGF receptor expression.

Expression of TGF- $\alpha$ mRNA and its receptor mRNA in cultured pituitary cells was studied using an RT-PCR 
method. To study whether TGF- $\alpha$ mediates the oestrogen-induced proliferation of pituitary cells or not, a specific inhibitor of EGF receptors, 3,4-dimethoxy-a-(3pyridyl)-(Z)-cinnamonitrile (RG-13022) (Yaish et al. 1988, Yoneda et al. 1991), was used in this experiment. Moreover, the blockade of TGF- $\alpha$ message translation was attempted by treatment with TGF- $\alpha$ antisense oligodeoxynucleotide (ODN) to clarify the molecular mechanism of oestrogen-induced pituitary growth.

\section{Materials and Methods}

\section{Animals}

Male ICR mice (CLEA Japan Inc., Osaka, Japan) were kept in a temperature-controlled animal room, and given a commercial diet, CE-7 (CLEA Japan Inc.), and freely available tap water. All animal care and experiments were performed in accordance with the Guidelines of Animal Experimentation, Faculty of Science, Okayama University, Japan, and the NIH Guide for the Care and Use of Laboratory Animals, USA.

\section{Isolation of pituitary cells}

Anterior pituitaries obtained from 2-month-old male mice were dissociated with $0.5 \%$ trypsin $(0.5 \% \mathrm{w} / \mathrm{v}$; DIFCO, Detroit, MI, USA) as previously described (Oomizu et al. 1998). Cell viability was checked using a trypan blue exclusion test and was usually more than 95\%. The isolated pituitary cells were suspended in a 1:1 mixture of Dulbecco's modified Eagle's medium and Ham's F12 medium without phenol red (DMEM/F12 medium; Sigma Chemical Co., St Louis, MO, USA) containing fetal calf serum (FCS, 10\% v/v). They were seeded on poly-L-lysine (Sigma)-coated plastic coverslips (diameter $13 \mathrm{~mm}$; Sumitomo, Tokyo, Japan) in 24-well tissue culture plates (Becton Dickinson, Lincoln Park, NJ, USA) at a cell density of $5 \times 10^{5}$ cells $/ \mathrm{ml}$ per well. Culture was carried out in a humidified atmosphere of $5 \% \mathrm{CO}_{2}$ and $95 \%$ air at $37^{\circ} \mathrm{C}$.

\section{Cell treatment}

After a 3-day culture in DMEM/F-12 medium containing $10 \%$ FCS to enhance cell attachment, the pituitary cells were cultured in serum-free DMEM/F-12 medium supplemented with hydrocortisone $(100 \mu \mathrm{g} / \mathrm{l})$, triiodothyronine $(400 \mathrm{ng} / \mathrm{l})$, transferrin $(10 \mathrm{mg} / \mathrm{l})$, bovine glucagon (10 ng/l), parathyroid hormone (200 ng/l), insulin (1 $\mu \mathrm{g} / \mathrm{l})$ and sodium selenite $(5 \mu \mathrm{g} / \mathrm{l})$ for another 3 days. Subsequently, TGF- $\alpha$ (human recombinant; Amersham International, Amersham, Bucks, UK), and oestradiol-17 $\beta$ $\left(\mathrm{OE}_{2}\right.$, Sigma) treatment was performed for 5 days in the serum-free defined medium. $\mathrm{OE}_{2}$ was initially dissolved in ethanol at a concentration of $10 \mu \mathrm{M}(0 \cdot 03 \%$ ethanol). A working solution was prepared before use by diluting the stock solution with the culture medium. The medium was changed every 2 days during the 5-day treatment. Each treatment was performed on three plastic coverslips.

\section{Immunocytochemical detection of cell proliferation and pituitary hormones}

DNA-synthesizing cells and pituitary secretory cell types were determined by dual-labelling immunocytochemical detection of bromodeoxyuridine (BrdU) and pituitary hormones as described previously (Oomizu et al. 1998). Briefly, BrdU was added to the culture medium ( $3 \mathrm{mg}$ / $\mathrm{ml}$ ). After a 12-h incubation in the BrdU solution, the cultured cells were fixed with Bouin's solution for $30 \mathrm{~min}$ at room temperature. Immunocytochemical detection of BrdU was performed using a commercial kit (Amersham). The immunoreactivity of BrdU was detected using 3,3'diaminobenzidine tetrahydrochloride (DAB) with nickel chloride as a chromogen (Hsu \& Soban 1982). The BrdU-labelled nuclei were manifested as purplish blue. Following detection of BrdU-labelled cells, pituitary hormone-producing cells were immunocytochemically stained by the avidin-biotin-peroxidase complex technique (Hsu et al. 1980) to identify secretory cell types of the DNA-synthesizing cells. The plastic coverslips which had been already immunostained with monoclonal antibody against BrdU were treated with $0.3 \%$ hydrogen peroxide in absolute methanol for $20 \mathrm{~min}$ at room temperature to block peroxidase activity. The cells were incubated for $1 \mathrm{~h}$ at room temperature in a humidified box with one of the polyclonal antibodies raised against pituitary hormones: rabbit anti-pig ACTH (1:2000; Advance, Tokyo, Japan); rabbit anti-rat thyroid-stimulating hormone (TSH) $\beta$ (1:2000; anti-rBetaTSH-IC-1, National Institute of Diabetes, Digestive and Kidney Diseases (NIDDK), Bethesda, MD, USA); guinea pig anti-rat luteinizing hormone $(\mathrm{LH}) \beta(1: 2500$; anti-rBetaLH-IC-2, NIDDK); guinea pig anti-rat follicle-stimulating hormone (FSH) $\beta$ (1:2000; anti-rBetaFSH-IC-1, NIDDK); monkey anti-mouse growth hormone $(\mathrm{GH}) \quad(1: 2000$; \#35, NIDDK); and rabbit anti-mouse PRL (1:2000; Shikibo, Kusatsu, Japan). Following the incubation, the cells were washed with $0.01 \mathrm{M}$ PBS, and the second antiserum (biotinylated anti-rabbit $\operatorname{IgG}$, anti-monkey $\operatorname{IgG}$ or antiguinea pig IgG antiserum, 1:200) was applied for $30 \mathrm{~min}$. The cells were washed with PBS, and then the third reagent (avidin-biotin-peroxidase complex) was applied for $30 \mathrm{~min}$ at room temperature. The immunoreactivities of pituitary hormones were detected using DAB solution without nickel chloride. The pituitary hormones were manifested as brown, and the colour was easily distinguished from the purplish blue of the BrdU-labelled nuclei (Oomizu et al. 1998).

The specificity of the immunostaining for pituitary hormones was tested by omission of each primary antibody 
or by the use of primary antibodies (working dilution, $100 \mu \mathrm{l})$ preabsorbed with $10 \mu \mathrm{g}$ of each highly purified pituitary hormone $(\mathrm{ACTH}$, rat TSH, rat $\mathrm{LH}$, rat FSH, rat $\mathrm{GH}$ and rat PRL) at $4{ }^{\circ} \mathrm{C}$ for $24 \mathrm{~h}$. These controls did not show any staining. The specificity of antibodies to mouse $\mathrm{GH}$ and PRL was also checked with the immunoblotting assay (Takahashi \& Osawa 1994). The validity of duallabelling immunocytochemical detection was tested by omitting either the antibody to BrdU or antibodies to pituitary hormones. Without the antibody to BrdU, immunostaining of the pituitary hormones was not altered. Without antibodies to pituitary hormones, immunostaining of $\mathrm{BrdU}$ was not altered.

\section{Quantification of the immunolabelled cells}

The cells were observed under a light microscope at $\times 600$ magnification. The fields were scanned across the coverslip to avoid overlap. In each field immunopositive cells and immunonegative cells were counted, and more than 1000 cells were observed from each coverslip. The percentages of BrdU-labelled cells were expressed as those cells that had a densely labelled (purplish blue) nucleus in the total cells. Each group consisted of three coverslips.

\section{$R G-13022$ treatment}

RG-13022 (BIOMOL Research Laboratories Inc., Plymouth Meeting, PA, USA) is a specific inhibitor of the tyrosine kinase of EGF receptors (Yoneda et al. 1991). The effect of RG-13022 on the proliferation of the pituitary cells was studied to determine whether the $\mathrm{OE}_{2}$-induced proliferation of pituitary cells was regulated through EGF receptors or not. Pituitary cells were treated with EGF (Sigma, $10 \mathrm{ng} / \mathrm{ml})$ or $\mathrm{OE}_{2}\left(10^{-9} \mathrm{M}\right)$ for 5 days in the presence or absence of RG-13022 (10 $\left.{ }^{-7} \mathrm{M}\right)$. RG-13022 was diluted in the culture medium following the method described previously (Yoneda et al. 1991).

\section{TGF- $\alpha$ antisense $O D N$ and EGF antisense ODN treatment}

TGF- $\alpha$ antisense ODN and EGF antisense ODN were used to block TGF- $\alpha$ or EGF message translation respectively. All 15 mer ODNs were purchased from Funakoshi (Tokyo, Japan). The sequence of TGF- $\alpha$ antisense ODN is based on the murine cDNA sequence. The sequence of TGF- $\alpha$ antisense ODN was designed not to form any stable secondary structure at physiological salt concentration and temperature $\left(37^{\circ} \mathrm{C}\right)$. The sequence of TGF- $\alpha$ antisense ODN which is complementary to the translation initiation site of TGF- $\alpha$ mRNA is $5^{\prime}$ GACCATCTTCCGAGC- $3^{\prime}$, and that of TGF- $\alpha$ sense ODN is $5^{\prime}$-GCTCGGAAGATGGTC- $3^{\prime}$. The sequence of EGF antisense ODN is based upon the report by Roy \& Harris (1994), and in their study this EGF antisense ODN inhibited FSH-induced DNA synthesis in hamster preantral follicles. The sequence of EGF antisense ODN complementary to the sequence of translation initiation site of EGF mRNA is 5'-TCGGCCCCAGGG CAT $3^{\prime}$, and that of EGF sense ODN is $5^{\prime}$ ATGCCCTGGGGCCGA-3'. After a 6-day preculture, pituitary cells were cultured in antisense ODN or sense ODN $(2.5 \mathrm{nmol})$ and $\mathrm{OE}_{2}\left(10^{-9} \mathrm{M}\right)$ for 5 days. The medium containing ODNs and $\mathrm{OE}_{2}$ was added everyday, and the whole medium was exchanged only on the 3rd day of ODN treatment.

\section{Reverse transcription-polymerase chain reaction (RT-PCR)}

PCR primers Primers for TGF- $\alpha$ and EGF receptors are based on the mouse sequence data, and those for the $\beta$-actin are based on a previous report (Matsuda \& Mori 1997). These sequences and the location of nucleotide sequences were as follows, TGF- $\alpha$ 5' (AGCCAGAA GAAGCAAGCCATCACT, 367-390), TGF- $\alpha$ 3' (CT CATTCTCGGTGTGGGTTAGCAA, 845-868), EGF receptor 5' (GTGTGAAGAAGTGCCCCCGAAAC, 931-953), EGF receptor $3^{\prime}$ (AACGACCGCCAAA GAAAACTGACC, $1359-1382$ ), $\beta$-actin $5^{\prime}$ (TCTA GACTTCGAGCAGGAGATGGCC, 740-764), $\beta$-actin 3' (CTAGAAGCACTTGCGGTGCACGATG, 11841208). These primers generate PCR products of 502 , 452 and 469 bp for TGF- $\alpha$, EGF receptor and $\beta$-actin respectively. These primers were synthesized by Gibco BRL Custom Primers, Life Technologies Asia Pacific (Yokohama, Japan).

cDNA synthesis and PCR amplification Total RNA from anterior pituitaries of adult female mice was prepared following the method of Chomczynski \& Sacchi (1987). Total RNA $(1 \mu \mathrm{g})$ in a final volume of $20 \mu \mathrm{l}$ was subjected to the reverse transcription reaction using Superscript II Reverse Transcriptase (Gibco BRL) with random primers according to the manufacturer's instructions. Each PCR was performed using primer pairs specific for TGF- $\alpha$, EGF receptors or $\beta$-actin. The PCRs were carried out using AmpliTaq Gold DNA polymerase (Applied Biosystems, Branchburg, NJ, USA). The conditions for the PCR were as follows: after activation of the DNA polymerase by incubating for $9 \mathrm{~min}$ at $95^{\circ} \mathrm{C}, 40$ cycles (for TGF- $\alpha$ mRNA amplification), 35 cycles (for EGF receptor mRNA amplification) and 30 cycles (for $\beta$-actin mRNA amplification) of reactions including denaturation for $30 \mathrm{~s}$ at $95^{\circ} \mathrm{C}$ and extension for $1 \mathrm{~min}$ at $60{ }^{\circ} \mathrm{C}$ were performed, followed by an additional extension for $10 \mathrm{~min}$ at $60{ }^{\circ} \mathrm{C}$.

PCR product detection A $10 \mu \mathrm{l}$ of aliquot of each reaction was electrophoresed on a $2 \cdot 0 \%$ agarose gel, which was stained with ethidium bromide, photographed under ultraviolet illumination and compared with a known standard (100 bp DNA Ladder; Gibco BRL, 
Gaithersburg, MD, USA) for size determination. The PCR products were transferred onto Hybond $\mathrm{N}^{+}$membrane (Amersham). The DNA fragments of TGF- $\alpha$ amplified by RT-PCR were subcloned into pGEM3Zf $(+)$ and subjected to sequencing. The $502 \mathrm{bp}$ product for TGF- $\alpha$ cDNA contained a coding sequence identical to the reported sequence of mouse TGF- $\alpha$ with the exception of one nucleotide (in the $5^{\prime}$ non-coding region). A $1.8 \mathrm{~kb}$ human EGF receptor cDNA clone (pHER-A64-1) was obtained from the American Type Culture Collection (Rockville, MD, USA). These cDNAs were used as probes for Southern blotting analysis. Blots were exposed to Fuji Medical X-ray film (Fuji Film, Tokyo, Japan). Southern blotting analysis verified that the $502 \mathrm{bp}$ band and $452 \mathrm{bp}$ band corresponded to TGF- $\alpha$ cDNA and EGF receptor cDNA respectively.

RT-PCR product quantification PCR products were electrophoresed and stained with ethidium bromide. Stained gels were photographed. Band intensity was measured from the photographs using NIH Image (version 1.61) (NIH, Bethesda, MD, USA). For quantification of mRNA production, different amounts of RT products $(0 \cdot 5,1,1 \cdot 5$ and $2 \mu \mathrm{l})$ were used for PCR, and the linear range for amplification was confirmed. Based upon the data from the linear range analysis for amplification of mRNAs, we measured band intensity of PCR products using $1 \mu \mathrm{l}$ of RT products. RT-PCR was calibrated by the intensity of the $\beta$-actin band amplified from the same sample. The ratio of the intensity of the TGF- $\alpha$ band or the EGF receptor band to the intensity of the $\beta$-actin band was used as a relative measure of mRNA abundance.

\section{Statistics}

Data are presented as the mean \pm s.E.M. The doseresponse curves were analysed by one-way ANOVA, followed by Duncan's multiple range test. The other data were analysed by Duncan's multiple range test. Differences of $P<0 \cdot 05$ were considered as statistically significant. Three independent experiments were performed in each study.

\section{Results}

Effects of $\mathrm{OE}_{2}$ on proliferation of pituitary cells

The pituitary cell types of BrdU-labelled cells were immunocytochemically determined using antibodies raised against pituitary hormones. BrdU was detected in all subsets of hormone-producing cells. This indicates that all types of pituitary secretory cells were able to proliferate in the present culture system. We had previously shown that $\mathrm{OE}_{2}\left(10^{-9} \mathrm{M}\right)$ stimulated cell proliferation in primary cultures of pituitary cells (Oomizu \& Takahashi 1996). In the present study pituitary cells were treated with $\mathrm{OE}_{2}$ $\left(10^{-9} \mathrm{M}\right)$ for 5 days. $\mathrm{OE}_{2}$ significantly stimulated $\mathrm{BrdU}$

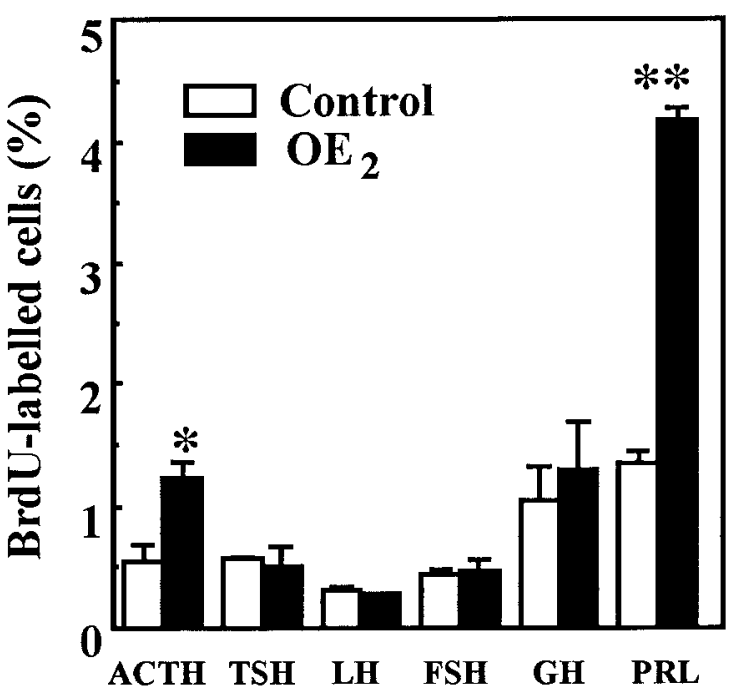

Figure 1 Percentages of pituitary secretory cells, with or without $\mathrm{OE}_{2}$ treatment $\left(10^{-9} \mathrm{M}\right)$ for 5 days, with a BrdU-labelled nucleus. BrdU was immunocytochemically detected and the number of BrdU-labelled cells was counted in triplicate. Columns and the bars above indicate means and standard errors. ACTH, corticotrophs; TSH, thyrotrophs; $\mathrm{LH}$, LH-secreting gonadotrophs; $\mathrm{FSH}, \mathrm{FSH}$-secreting gonadotrophs; $\mathrm{GH}$, somatotrophs; PRL, mammotrophs. ${ }^{*} P<0 \cdot 05,{ }^{*} P<0 \cdot 01$, significantly different compared with corresponding control.

labelling in mammotrophs approximately 3 -fold $(P<0 \cdot 01)$ and corticotrophs approximately 2 -fold $(P<0 \cdot 05)$, but not in any other subset of pituitary cells (Fig. 1).

\section{Effects of TGF- $\alpha$ on proliferation of pituitary cells}

Pituitary cells were cultured with various concentrations of TGF- $\alpha(0 \cdot 01-10 \mathrm{ng} / \mathrm{ml})$ for 5 days. The percentages of BrdU-labelled cells were higher than those of controls when $0 \cdot 1$ and $1 \mathrm{ng} / \mathrm{ml}$ of TGF- $\alpha$ were added to the culture medium (Fig. 2). TGF- $\alpha$ at $10 \mathrm{ng} / \mathrm{ml}$ decreased the percentage of BrdU-labelled cells, but this was statistically not significant. This inhibitory response of TGF- $\alpha$ at high concentration was reproducibly detected in three independent experiments.

\section{Effect of RG-13022 treatment on proliferation of pituitary cells}

To confirm that EGF receptors may be involved in an autocrine or paracrine mechanism regulating oestrogen action, we investigated the effect of R G-13022, a specific EGF receptor inhibitor, on oestrogen-induced cell proliferation. RG-13022 at concentrations higher than $10^{-8}$ $\mathrm{M}$ significantly inhibited the increase in the percentage of BrdU-labelled cells by EGF treatment $(10 \mathrm{ng} / \mathrm{ml}$ ) (data not shown), and in the following studies $10^{-7} \mathrm{M}$ RG-13022 was used. $\mathrm{OE}_{2}$-induced proliferation of 


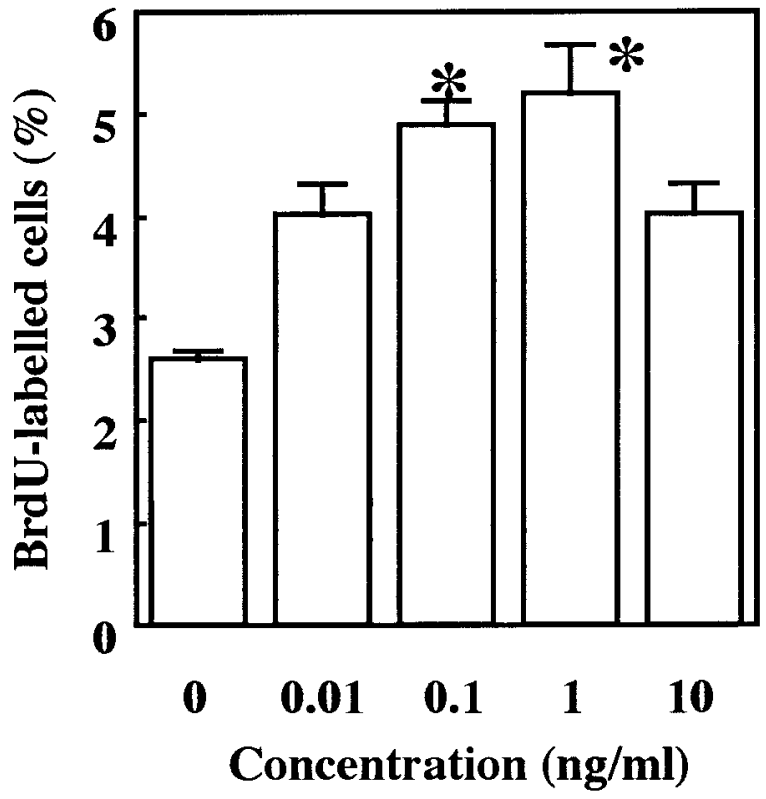

Figure 2 Effect of TGF- $\alpha$ on the percentage of BrdU-labelled pituitary cells. TGF- $\alpha$ at various concentrations was added to the culture media for 5 days. The number of BrdU-labelled cells was counted in triplicate. Columns and the bars above indicate means and standard errors. ${ }^{*} P<0 \cdot 05$, significantly different compared with control $(0 \mathrm{ng} / \mathrm{ml})$. This experiment was repeated two additional times for TGF- $\alpha$ with similar results.

mammotrophs and corticotrophs was inhibited by RG$13022(P<0 \cdot 01$, Fig. 3). Our previous study demonstrated that insulin $(10 \mu \mathrm{g} / \mathrm{ml})$ stimulated proliferation of pituitary cells (Oomizu \& Takahashi 1996). In the present study, RG-13022 did not inhibit insulin-induced cell proliferation (data not shown). Even in the absence of EGF or $\mathrm{OE}_{2}, \mathrm{RG}-13022$ inhibited the number of BrdU-labelled mammotrophs and corticotrophs (Fig. 3).

\section{Effect of TGF- $\alpha$ antisense ODN or EGF antisense ODN treatment on proliferation of pituitary cells}

$\mathrm{OE}_{2}$ significantly increased the number of BrdU-labelled cells (Fig. 4). TGF- $\alpha$ antisense ODN treatment significantly attenuated the $\mathrm{OE}_{2}$-induced increase in the number of BrdU-labelled cells compared with the TGF- $\alpha$ sense ODN treatment $(P<0 \cdot 01)$. On the other hand, neither EGF antisense ODN nor EGF sense ODN treatment affected $\mathrm{OE}_{2}$-induced BrdU incorporation. Thus, blockage of TGF- $\alpha$ translation by TGF- $\alpha$ antisense ODN treatment nullified $\mathrm{OE}_{2}$-induced cell proliferation.

\section{$R T-P C R$ analysis of TGF- $\alpha m R N A$ and EGF receptor $m R N A$}

Various amounts of RT products $(0 \cdot 5,1,1.5$ and $2 \mu \mathrm{l}$ for TGF- $\alpha$ and $\beta$-actin; $0 \cdot 5,1$, and $1 \cdot 5 \mu$ for EGF receptor) were amplified by PCR to ensure the linear range for
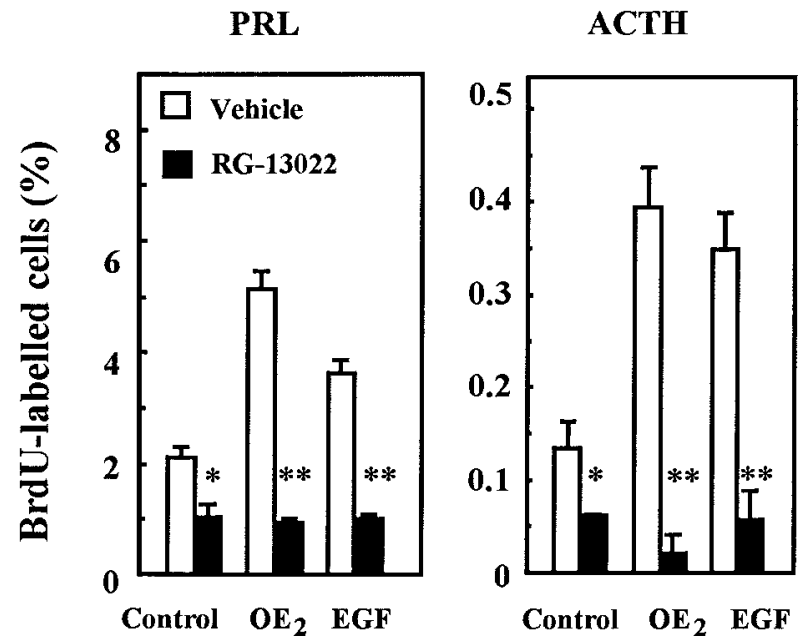

Figure 3 Effect of RG-13022 $\left(10^{-7} \mathrm{M}\right)$ on the percentages of BrdU-labelled mammotrophs (PRL) or corticotrophs (ACTH) under $\mathrm{OE}_{2}\left(10^{-9} \mathrm{M}\right)$ treatment, or EGF $(10 \mathrm{ng} / \mathrm{ml})$ treatment. The number of BrdU-labelled cells was counted in triplicate. Columns and the bars above indicate means and standard errors. ${ }^{*} P<0 \cdot 05$, ${ }^{* \star} P<0 \cdot 01$, significantly different compared with corresponding control. The experiment was repeated twice with similar results.

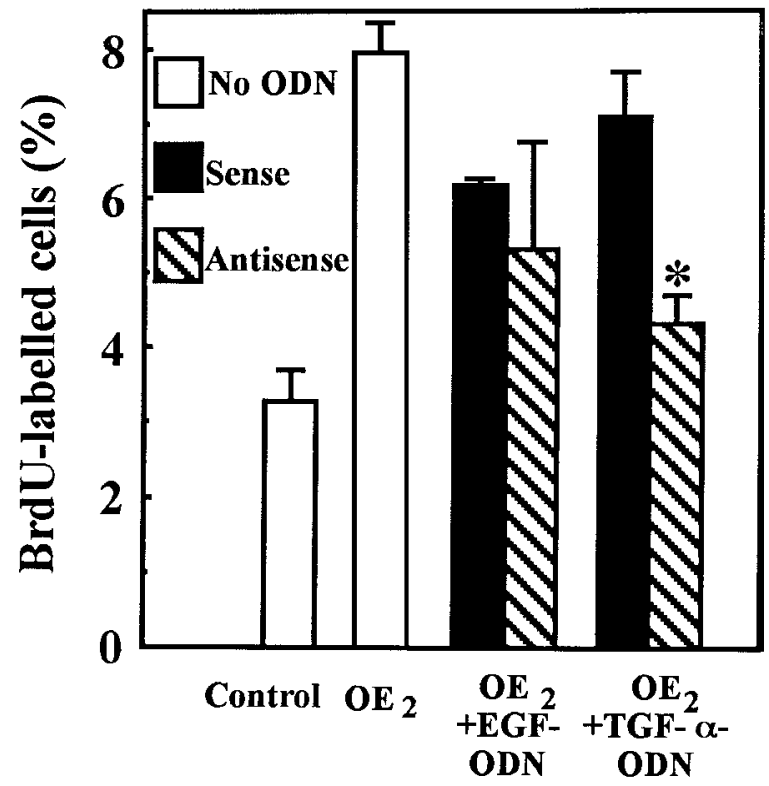

Figure 4 Effect of TGF- $\alpha$ ODN or EGF antisense ODN on the percentage of BrdU-labelled cells under $\mathrm{OE}_{2}\left(10^{-9} \mathrm{M}\right)$ treatment. The number of BrdU-labelled cells was counted in triplicate. Columns and the bars above indicate means and standard errors. ${ }^{*} P<0 \cdot 01$, significantly different compared with corresponding sense ODN treatment. The experiment was repeated twice with similar results.

amplification (Fig. 5A). PCR products for TGF- $\alpha$ mRNA, EGF receptor mRNA and $\beta$-actin mRNA increased in accordance with the increase in the amount of RT products. TGF- $\alpha$ mRNA levels and EGF receptor 
$\mathbf{A}$

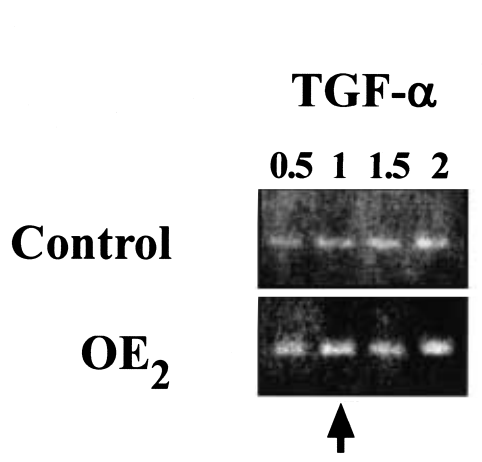

B

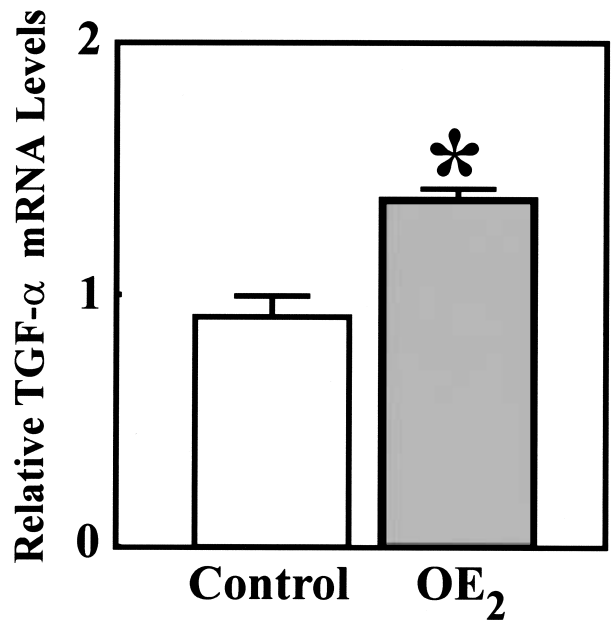

\section{Amount of RT products $(\mu \mathrm{l})$}

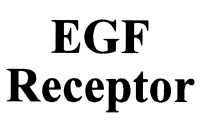

0.511 .5

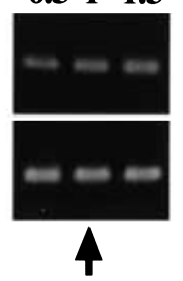

$\beta$-actin

$\begin{array}{llll}0.5 & 1 & 1.5 & 2\end{array}$

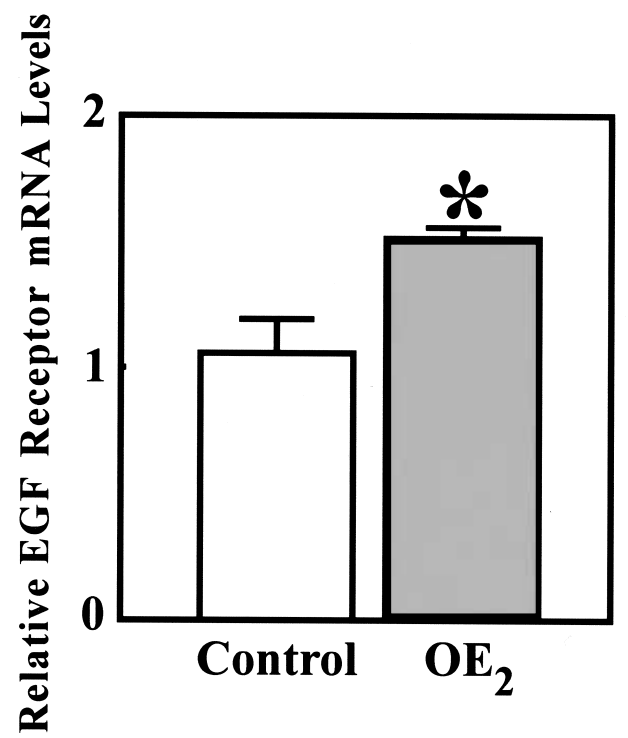

Figure 5 Effect of $\mathrm{OE}_{2}$ on the amount of TGF- $\alpha$ mRNA and EGF receptor mRNA in pituitary cells. (A) $0 \cdot 5,1,1 \cdot 5$ and $2 \mu \mathrm{l}$ of RT products (for TGF- $\alpha$ and $\beta$-actin) from the control sample and the $\mathrm{OE}_{2}$-treated sample were subjected to PCR. Amplified CDNA bands of TGF- $\alpha$, EGF receptor and $\beta$-actin were stained with ethidium bromide. The band intensities were increased with increasing amount of RT products of TGF- $\alpha$, EGF receptor and $\beta$-actin. (B) Relative amounts of TGF- $\alpha$ mRNA and EGF receptor mRNA were measured by the band intensities of $1 \mu \mathrm{l}$ of RT products (arrows in $(\mathrm{A})$ ). Mean and standard error of the means were calculated from three independent experiments. ${ }^{*} P<0 \cdot 01$ vs control.

mRNA levels were determined using $1 \mu \mathrm{l}$ of RT product, and normalized with respect to the intensity of the $\beta$-actin band. PCR analysis in this condition revealed that $\mathrm{OE}_{2}$ treatment $\left(10^{-9} \mathrm{M}\right)$ for 5 days increased TGF- $\alpha$ mRNA and EGF receptor mRNA levels compared with control treatment (Fig. 5B; $P<0 \cdot 05$ respectively).

\section{Discussion}

Several growth factors are synthesized in pituitary glands, and exert roles within the gland (Schwartz \& Cherny
1992, Renner et al. 1996, Ray \& Melmed 1997). Some of those growth factors may be involved in the oestrogeninduced growth of pituitary cells. Borgundvaag et al. (1992) found a concurrent increase in pituitary weights and TGF- $\alpha$ mRNA levels by chronic oestrogen treatment, and from this correlation they suggested that oestrogeninduced pituitary growth was mediated by TGF- $\alpha$. However, direct evidence for involvement of TGF- $\alpha$ in oestrogen-induced pituitary growth had not been provided. Using the serum-free culture of mouse pituitary cells we finally demonstrated that oestrogen action on the 
proliferation of mammotrophs and corticotrophs was indirect, and was probably mediated by TGF- $\alpha$ synthesized in the pituitary cells and acting through the EGF receptor.

The proliferation of mammotrophs and corticotrophs was stimulated by oestrogen. This oestrogen-induced growth was inhibited by treatment with RG-13022. This finding indicates that the oestrogen action was mediated through EGF receptors. TGF- $\alpha$ antisense ODN treatment decreased the $\mathrm{OE}_{2}$-induced proliferation of pituitary cells. Our preliminary study on $\mathrm{GH}_{3}$ cells showed that TGF- $\alpha$ antisense ODN treatment decreased TGF- $\alpha$ immunoreactivity, although the treatment did not affect the number of TGF- $\alpha$-producing cells (T Kakeya, T Masui \& $\mathrm{S}$ Takahashi, unpublished observation). This result indicates that TGF- $\alpha$ antisense ODN treatment could decrease TGF- $\alpha$ synthesis. Therefore, the reduction of cell proliferation by TGF- $\alpha$ antisense ODN treatment is considered to be caused by interruption of TGF- $\alpha$ synthesis and the decrease in TGF- $\alpha$ levels. RT-PCR analysis revealed that oestrogen increased TGF- $\alpha$ mRNA levels. It is highly probable that oestrogen enhances TGF- $\alpha$ synthesis, and in turn, TGF- $\alpha$ stimulates the proliferation of mammotrophs and corticotrophs. Considering these results together, we conclude that TGF- $\alpha$ is a physiological mediator of oestrogen action.

The RT-PCR study identified TGF- $\alpha$ mRNA in the mouse pituitary cells, but the expression of the growth factor protein remains to be studied. Fan \& Childs (1995), using in situ hybridization, reported that somatotrophs, gonadotrophs and mammotrophs expressed TGF- $\alpha$ mRNA in rat pituitaries. These findings, together with our finding, support a hypothesis that TGF- $\alpha$ synthesized in the pituitary glands regulates pituitary functions in a paracrine or autocrine manner. Overexpression of human TGF- $\alpha$ induced in transgenic mice accelerates the development of pituitary mammotrophic adenoma (McAndrew et al. 1995). In pituitary tumour cells, TGF- $\alpha$ affects cell proliferation in either a stimulatory or inhibitory manner (Ramsdell 1991, Finley \& Ramsdell 1994, Ezzat et al. 1995). Thus, TGF- $\alpha$ is involved in the growth of normal and tumour pituitary cells.

EGF and TGF- $\alpha$ are considered to exert actions through the same receptor, the EGF receptor (Massague 1990). Fan \& Childs (1995) found that subsets of all types of rat pituitary cells expressed EGF receptors, including mammotrophs and corticotrophs. EGF receptor mRNA was detected in mouse pituitary cells using RT-PCR. Mammotrophs and corticotrophs were considered to express EGF receptors, since the proliferation of mammotrophs and corticotrophs was blocked by specific EGF receptor inhibitor RG-13022 treatment in vitro.

Even in the absence of EGF, RG-13022 inhibited mammotrophic and corticotrophic proliferation. This suggests that pituitary cells produce TGF- $\alpha$ at levels sufficient to stimulate cell proliferation in the present culture system, and that RG-13022 inhibited the stimulatory effect of endogenous TGF- $\alpha$.

Oestrogen-stimulated EGF release from rat pituitary cells has been reported (Mouihate \& Lestage 1995). Our preliminary study could not detect stimulatory effects of oestrogen on EGF synthesis in cultured pituitary cells by RT-PCR (S Oomizu, S Takeuchi \& S Takahashi, unpublished observation). In addition, the EGF antisense ODN treatment failed to affect the $\mathrm{OE}_{2}$-induced proliferation of pituitary cells. We have not yet determined EGF release from the mouse pituitary cells. Therefore, the possibility cannot be excluded that pituitary EGF is involved in oestrogen-induced pituitary growth.

EGF receptor expression changes with various conditions such as stress and the oestrous cycle (Fan et al. 1995, Fan \& Childs 1995, Armstrong \& Childs 1997a,b). Oestrogen stimulates EGF receptor levels in the rat uterus (Mukku \& Stancel 1985). RT-PCR analysis showed that oestrogen stimulated EGF receptor expression at the transcription level. The expression of EGF receptor mRNA in mammotrophs and corticotrophs may be enhanced by oestrogen, although the types of EGF receptor-expressing cells have not been determined. Thus, oestrogen stimulates pituitary growth at these two levels - TGF- $\alpha$ production and EGF receptor production.

TGF- $\beta 1$ inhibits proliferation of mammotrophs (Sarkar et al. 1992). Mammotrophs synthesize TGF- $\beta 1$, and TGF- $\beta 1$ synthesis is inhibited by oestrogen (Burns \& Sarkar 1993). Expression of TGF- $\beta 1$ type II receptors in pituitary cells is reduced by oestrogen treatment (De et al. 1996). Therefore, another mechanism of oestrogeninduced pituitary growth is possible, such that oestrogen could inhibit pituitary TGF- $\beta 1$ production, resulting in the reduction of TGF- $\beta 1$-induced inhibition of mammotroph proliferation.

Several reports have indicated that oestrogen affects corticotrophic functions. In the baboon fetal pituitary oestrogen stimulates the expression of proopiomelanocortin mRNA and the proliferation of corticotrophs (Pepe et al. 1994). In ovariectomized female rats, oestrogen enhanced the responsiveness of corticotrophs to a stressful stimulus (Burgess \& Handa 1992). Furthermore, we found that oestrogen stimulated the proliferation of corticotrophs in the mouse pituitary cells. Considering the findings that TGF- $\alpha$ synthesis and EGF release were regulated by oestrogen in the rat pituitary (Borgundvaag et al. 1992, Mouihate \& Lestage 1995), it is probable that oestrogen regulates corticotrophic functions through the activation of EGF receptors.

In conclusion, oestrogen and TGF- $\alpha$ stimulated the proliferation of mammotrophs and corticotrophs in vitro. Oestrogen-induced growth of mammotrophs and corticotrophs was mediated through EGF receptors. It is highly probable that TGF- $\alpha$ mediates the stimulatory effect of oestrogen on proliferation of mammotrophs and corticotrophs, since blockage of TGF- $\alpha$ production by TGF- $\alpha$ 
antisense ODN treatment inhibited the oestrogenic proliferation. Oestrogen stimulates TGF- $\alpha$ EGF receptor expression at the transcription level.

\section{Acknowledgements}

The authors would like to thank the National Hormone and Pituitary Program, NIDDK, NIH, Bethesda, MD, USA for the kind supply of antibodies to pituitary hormones. This study was supported in part by Grants-in-aid for Scientific Research from the Ministry of Education, Science, Sports and Culture, Japan to S T.

\section{References}

Armstrong J \& Childs GV 1997a Changes in expression of epidermal growth factor receptors by anterior pituitary cells during the estrous cycle: cyclic expression by gonadotropes. Endocrinology $\mathbf{1 3 8}$ 1903-1908.

Armstrong JL \& Childs GV $1997 b$ Regulation of expression of epidermal growth factor receptors in gonadotropes by epidermal growth factor and estradiol: studies in cycling female rats. Endocrinology 138 5434-5441.

Bethea CL 1984 Stimulatory effect of estrogen on prolactin secretion from primate pituitary cells cultured on extracellular matrix and in serum-free medium. Endocrinology 115 443-451.

Borgundvaag B, Kudlow JE, Mueller SG \& George SR 1992 Dopamine receptor activation inhibits estrogen-stimulated transforming growth factor- $\alpha$ gene expression and growth in anterior pituitary, but not in uterus. Endocrinology 130 3453-3458.

Burgess LH \& Handa RJ 1992 Chronic estrogen-induced alterations in adrenocorticotropin and corticosterone secretion, and glucocorticoid receptor-mediated functions in female rats. Endocrinology 131 1261-1269.

Burns G \& Sarkar DK 1993 Transforming growth factor $\beta 1$-like immunoreactivity in the pituitary gland of the rat: effect of estrogen. Endocrinology 133 1444-1449.

Childs GV, Rougeau D \& Unabia G 1995 Corticotropin-releasing hormone and epidermal growth factor: mitogens for anterior pituitary corticotropes. Endocrinology 136 1595-1602.

Chomczynski P \& Sacchi N 1987 Single-step method of RNA isolation by acid guanidinium thiocyanate-phenol-chloroform extraction. Analytical Biochemistry 162 156-159.

De A, Morgan TE, Speth RC, Boyadjieva N \& Sarkar DK 1996 Pituitary lactotrope expresses transforming growth factor $\beta$ (TGF $\beta$ ) type II receptor mRNA and protein and contains ${ }^{125}$ I-TGF $\beta 1$ binding sites. Journal of Endocrinology 149 19-27.

Ezzat S, Walpola IA, Ramyar L, Smyth HS \& Asa SL 1995 Membraneanchored expression of transforming growth factor-alpha in human pituitary adenoma cells. Journal of Clinical Endocrinology and Metabolism 80 534- 539.

Fan X \& Childs GV 1995 Epidermal growth factor and transforming growth factor- $\alpha$ messenger ribonucleic acids and their receptors in the rat anterior pituitary: localization and regulation. Endocrinology $1362284-2293$.

Fan X, Nagle GT, Collins TJ \& Childs GV 1995 Differential regulation of epidermal growth factor and transforming growth factor- $\alpha$ messenger ribonucleic acid in the rat anterior pituitary and hypothalamus induced by stresses. Endocrinology 136 873-880.

Finley EL \& Ramsdell JS 1994 A transforming growth factor- $\alpha$ pathway is expressed in $\mathrm{GH}_{4} \mathrm{C}_{1}$ rat pituitary tumors and appears necessary for tumor formation. Endocrinology 135 416-422.
Hsu SM \& Soban E 1982 Color modification of diaminobenzidine (DAB) precipitation by metallic ions and its application for double immunohistochemistry. Journal of Histochemistry and Cytochemistry $\mathbf{3 0}$ 1079-1082.

Hsu SM, Raine L \& Fanger H 1980 The use of avidin-biotinperoxidase complex $(\mathrm{ABC})$ in immunoperoxidase techniques: a comparison between $\mathrm{ABC}$ and unlabeled antibody (PAP) procedures. Journal of Histochemistry and Cytochemistry 29 $577-580$.

Kobrin MS, Asa SL, Samsoondar J \& Kudlow JE 1987 a-Transforming growth factor in the bovine anterior pituitary gland: secretion by dispersed cells and immunohistochemical localization. Endocrinology 121 1412-1416.

Kudlow JE \& Kobrin MS 1984 Secretion of epidermal growth factorlike mitogens by cultured cells from bovine anterior pituitary glands. Endocrinology 115 911- 917.

Lazar LM \& Blum M 1992 Regional distribution and developmental expression of epidermal growth factor and transforming growth factor- $\alpha$ mRNA in mouse brain by a quantitative nuclease protection assay. Journal of Neuroscience 12 1688-1697.

Lloyd HM, Meares JD \& Jacobi J 1975 Effects of oestrogen and bromocriptine on in vivo secretion and mitosis in prolactin cells. Nature 225 497-498.

Massague J 1990 Transforming growth factor- $\alpha$ : a model for membrane-anchored growth factors. Journal of Biological Chemistry 265 21393-21396.

Matsuda M \& Mori T 1997 Effect of hormones on expression of prolactin receptor messenger ribonucleic acids in pancreatic islets of adult female mice in vitro. Zoological Science 14 159-165.

McAndrew J, Paterson AJ, Asa SL, McCarthy KJ \& Kudlow JE 1995 Targeting of transforming growth factor- $\alpha$ expression to pituitary lactotrophs in transgenic mice results in selective lactotroph proliferation and adenomas. Endocrinology 136 4479-4488.

Mouihate A \& Lestage J 1995 Estrogen increases the release of epidermal growth factor from individual pituitary cells in female rats. Journal of Endocrinology 146 495-500.

Mukku VR \& Stancel GM 1985 Regulation of epidermal growth factor receptor by estrogen. Journal of Biological Chemistry 2609820 9824.

Oomizu S \& Takahashi S 1996 Insulin stimulates the proliferation of mouse anterior pituitary cells in vitro. Biomedical Research $\mathbf{1 7}$ 365-371.

Oomizu S, Takeuchi S \& Takahashi S 1998 Stimulatory effect of insulin-like growth factor I on proliferation of mouse pituitary cells in serum-free culture. Journal of Endocrinology 157 53-62.

Pepe GJ, Davies WA \& Albrecht ED 1994 Activation of the baboon fetal pituitary-adrenocortical axis at midgestation by estrogen: enhancement of fetal pituitary proopiomelanocortin messenger ribonucleic acid expression. Endocrinology 135 2581-2587.

Ramsdell JS 1991 Transforming growth factor- $\alpha$ and $-\beta$ are potent and effective inhibitors of $\mathrm{GH}_{4}$ pituitary tumor cell proliferation. Endocrinology 128 1981-1990.

Ray D \& Melmed S 1997 Pituitary cytokine and growth factor expression and action. Endocrine Reviews 18 206-228.

Renner U, Pagotto U, Arzt E \& Stalla GK 1996 Autocrine and paracrine roles of polypeptide growth factors, cytokines and vasogenic substances in normal and tumors pituitary function and growth: a review. European Journal of Endocrinology 135 $515-532$.

Roy SK \& Harris SG 1994 Antisense epidermal growth factor oligodeoxynucleotides inhibit follicle-stimulating hormone-induced in vitro DNA and progesterone synthesis in hamster preantral follicles. Molecular Endocrinology 8 1175-1188.

Sarkar DK, Kim KH \& Minami S 1992 Transforming growth factor- $\beta 1$ messenger RNA and protein expression in the pituitary gland: its action on prolactin secretion and lactotropic growth. Molecular Endocrinology 6 1825-1833 
Schwartz J \& Cherny R 1992 Intercellular communication within the anterior pituitary influencing the secretion of hypophysial hormones. Endocrine Reviews 13 453-475.

Sirbasku DA 1978 Estrogen induction of growth factors specific for hormone-responsive mammary, pituitary, and kidney tumor cells. Proceedings of the National Academy of Sciences of the USA 75 3786-3790.

Sutherland RL, Watts CKW \& Clarke CL 1988 Oestrogen actions. In Hormones and their Actions, part I, pp 197-215. Eds BA Cooke, RJB King \& HJ van der Molen. Amsterdam: Elsevier Science Publishers.

Takahashi S 1995 Development and heterogeneity of prolactin cells. International Review of Cytology 157 33-98.

Takahashi S \& Kawashima S 1987 Proliferation of prolactin cells in the rat: effects of estrogen and bromocriptine. Zoological Science 4 $855-860$.
Takahashi S \& Osawa T 1994 Decreased proliferation of pituitary cells of streptozotocin-induced diabetic rats in response to estradiol-17beta. Acta Anatomica 151 239-244.

Yaish P, Gazit A, Gilon C \& Levitzki A 1988 Blocking of EGFdependent cell proliferation by EGF receptor kinase inhibitors. Science 242 933-935.

Yoneda T, Lyall RM, Alsina MM, Pereons PE, Spada AP, Levitzki A, Zilberstein A \& Mundy GR 1991 The antiproliferative effects of tyrosine kinase inhibitors tyrphostins on a human squamous cell carcinoma in vitro and in nude mice. Cancer Research $\mathbf{5 1}$ $4430-4435$.

Received 14 June 1999

Accepted 11 January 2000 